\title{
The colonization history of Scots pine (Pinus sylvestris) in pristine and drained raised bogs in Latvia
}

\author{
Mihails Čugunovs ${ }^{1,2 *}$, Oḷggerts Nikodemus², lluta Dauškane³, Guntis Brūmelis ${ }^{3}$ \\ ${ }^{1}$ University of Eastern Finland, School of Forest Sciences, Yliopistokatu 7, Joensuu, P.O. Box 111 80101, Finland \\ ${ }^{2}$ University of Latvia, Faculty of Geography and Earth Sciences, Jelgavas 1, Rīga LV-1004, Latvia \\ ${ }^{3}$ University of Latvia, Faculty of Biology, Jelgavas 1, Rīga LV-1004, Latvia \\ ^Corresponding author, E-mail: mihails.cugunovs@uef.fi
}

\begin{abstract}
In this study, we determined the spatio-temporal patterns of Scots pine (Pinus sylvestris L.) colonization in a drained and an undrained raised bog in Latvia, in relation to climate data and drainage history. The age of trees was estimated and mapped. In the drained mire, tree groups with age 20 to 60 years covered an extensive area, and the time of colonization corresponded to a period of low precipitation and bog drainage. In the undrained mire, the age of Scots pine was mostly 30 to 50 years and the peak colonization likely occurred when the ground water level was deeper in a period of low precipitation. Thus, the evidence suggests that drainage is not the only factor driving the development of Scots pine stands in bogs in Latvia. Our results show that the impacts of other factors, such as climate, should also be considered in ecosystem restoration and management plans.
\end{abstract}

Key words: climate, drainage, raised bog, Scots pine.

\section{Introduction}

Peatlands cover approximately $20 \%$ of the land area in Europe, and $25 \%$ or $240000 \mathrm{~km}^{2}$ of this area is located in the Baltic Sea basin area, making up at least $14 \%$ of its territory (Vasander et al. 2003). In Latvia, peat deposits, i.e. peatlands of an area more than 1 ha and with peat depth more than $0.3 \mathrm{~m}$, cover roughly ten per cent of the total area of the country, i.e. $\sim 6400 \mathrm{~km}^{2}$ (Pakalne 2008).

The development of tree cover has been observed in many ombrotrophic bogs in Latvia during the last century, as has been documented elsewhere in Northern Europe (Linderholm 1999; Ohlson et al. 2001; Linderholm, Leine 2004), Central Europe (Frelechoux et al.2000a; Frelechoux et al. 2000b; Frelechoux et al. 2003; Obidzinski et al. 2009), and Canada (Pellerin, Lavoie 2003). As a result of overgrowing, the habitats and plant and animal species typical for raised bogs disappear and the growth and deposition of Sphagnum mosses is reduced, and these factors, in turn, affect the accumulation of carbon in mire ecosystems (Ohlson et al. 2001). Vegetation changes in raised bogs, including pine tree cover development, are often associated with drainage of a bog or its surrounding area (McDonald, Yin 1999; Sarkkola et al. 2005; Kuze, Priede 2008; Nusbaums 2008; Pakalne 2008). However, there is evidence that climate change by increase in air temperature and decrease in precipitation leads to regional changes in the groundwater table, thereby affecting peatlands (Ågren, Zackrisson 1990; Linderholm 1999; Linderholm, Leine 2004; van der Linden et al. 2008). In direct bog groundwater level measurements in neighbouring Estonia, an increase in groundwater level has been observed in topographically lower bog ridge-pool microtope, while there was a clearly decreasing trend in annual mean groundwater level in a higher-placed ridgehollow microtope, the changes possibly being linked to climatic trends (Kont et al. 2007).

Palaeoecological studies of subfossil trees preserved in peat also indicate impact of climate change on tree cover in mires (e.g., Eckstein et al. 2009; Moir et al.2010; Edvardsson et al. 2012). These studies explicitly demonstrate that there were periods in the past when large trees (mainly pines and oaks) developed in peatlands, either in the transition stage between fen and raised bog (Eckstein et al. 2009), or in the bog stage of peatland development, i.e. in the Sphagnum peat layer (Edvardsson et al. 2012). These studies predominantly link the phases of tree cover establishment in peatlands with optimal regional climatic conditions, e.g., low precipitation and/or elevated temperatures, which lead to the lowering of the groundwater table and more favourable conditions for tree cover development. Deposition of nutrients, mainly nitrogen, from the atmosphere can also have an important role in the development of tree cover in peatlands (Gunnarsson 2000). On a narrower scale, fires facilitate decreasing water levels in mires and a change of vegetation (Ronkainen et al. 2013), including the development of tree cover on peatlands (Pellerin, Lavoie 2003; Kucerova et al. 2008). Another locally relevant mechanism is the influence of forest harvesting in territories adjacent to peatlands, 
which might increase evapotranspiration on the mire due to loss of a windbreak, thus decreasing substrate wetness (Mitchell et al. 2001) or increase runoff to the mire due to decreased evapotranspiration from the harvested area.

Thus, there are several factors that can in harmony lead to tree cover development in peatlands in general and Scots pine establishment in raised bogs in particular. In fundamental as well as applied ecology, there is a need to understand the relative importance of these factors and the contribution of each, particularly regarding the development of tree cover in peatlands. However, notwithstanding the common regional trends, the case of each peatland will be unique in terms of the mechanisms controlling the development of its vegetation.

Installation of dams on streams and drainage ditches to raise the groundwater level has been a measure used in protected areas to restore the natural mire communities that have regressed due to impact of the human activities. This type of habitat restoration is based on the assumption that observed overgrowing of mires by shrubs and trees has been due to the drainage of the mires and their surrounding areas (Nusbaums 2008). However, the causes of historical development of tree cover have often not been considered sufficiently. In order to forecast how mire management will impact environmental processes, knowledge of the past changes in tree cover in relation to human-caused (drainage) and natural (climate change) factors is necessary (Holden et al. 2007).

The aim of this study was to describe the spatiotemporal structure of Scots pine cover in two mires located in the boreo-nemoral ecotone in Latvia. One was a mire with unaltered hydrology and the other was drained. We hypothesized that overgrowth with Scots pine occurred in both drained and undrained mires in periods of dry and warm climatic conditions, and also in the period before drainage system installation.

\section{Materials and methods}

\section{Study sites}

The study was carried out in two peatlands with areas of overgrowing pine (Pinus sylvestris L.) in Latvia: the drained Cena mire and the undrained Ances Dizpurvs mire (Fig. 1). Both mires are part of the Natura 2000 ecological network of protected areas in the territory of the European Union and are also Internationally Important Bird Areas. Longterm data collected in Lielais Kemeri mire on water level was also used in the study.

Cena mire is located $20 \mathrm{~km}$ to the south-west from Riga, at $56^{\circ} 51^{\prime} 11^{\prime \prime} \mathrm{N}, 23^{\circ} 50^{\prime} 42^{\prime \prime} \mathrm{E}$. It is a two-dome raised bog, presently covering around 2500 ha. Before drainage, in the 1930's Cena mire was one of the largest bogs in Latvia, with an area of 8983 ha. In Cena mire, raised bog vegetation dominates, with Sphagnum mosses (mainly Sphagnum magellanicum, Sphagnum rubellum, Sphagnum tenellum) and Oxycoccus spp., Ledum palustre, Eriophorum spp. and Carex spp. (Silamikele 2005). Vegetation typical for a transitional mire with Carex lasiocarpa, Carex limosa, Rhynchospora alba, Sphagnum teres, Sphagnum warnstorfi, and Sphagnum flexuosum occurs in the north-eastern part of the study area. The average peat depth in Cena mire is $4.3 \mathrm{~m}$, and the maximum depth reaches $6.8 \mathrm{~m}$ in the oldest, northern part of the mire. Small, old, stunted pines are known to grow even in the central parts of the mire, while near the bog lakes height of pine can reach

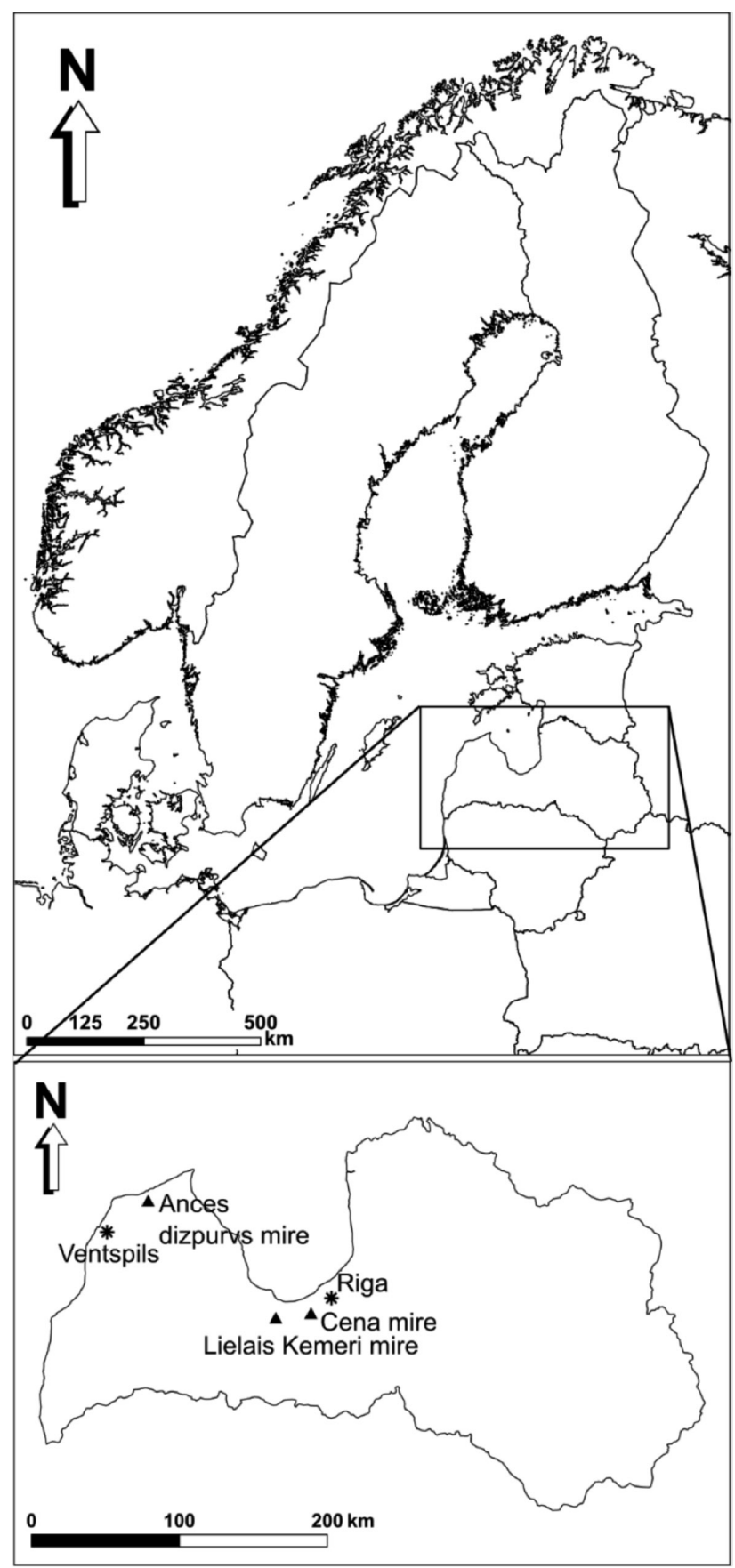

Fig. 1. Map showing the locations of the study sites in Northern Europe and Latvia. 
over $8 \mathrm{~m}$. Currently, the Cena mire ecosystem is bordered by drainage ditches and a peat extraction field (Silamikele 2005; Pakalne 2008). The most degraded area is in the western part of Cena mire, close to the peat extraction field that is still in operation. Colonization of P. sylvestris and Betula pubescens had occurred in this and the adjacent area (Figs. 2A-B), comprising about 150 ha in total, where the present study was carried out.

Ances Dizpurvs mire is located $35 \mathrm{~km}$ to the northeast from Ventspils, at $57^{\circ} 34^{\prime} 58^{\prime \prime} \mathrm{N}, 22^{\circ} 5^{\prime} 50^{\prime \prime} \mathrm{E}$. The mire is located in dune-valley terrain, which defines its shape and configuration, and covers about 1500 ha. The dominating vegetation in Ances Dizpurvs is typical for raised bogs, and dominated by Sphagnum fuscum, Sphagnum magellanicum, Sphagnum rubellum, Oxycoccus spp., Calluna vulgaris, and Eriophorum vaginatum. The average peat depth is $2.4 \mathrm{~m}$, and the maximum depth reaches $3.5 \mathrm{~m}$ (Peterhofs 2007). Stand density is higher on mineral soil islands (dunes) that are interspersed within the mire. Scots pine trees grow even in the mire expanse, although distributed sparsely. Tree cover is slightly denser towards the edges of the mire. The areas in the vicinity of the mire (and, possibly, the mire itself) have been affected by fires, mostly caused by the Soviet army, which previously held military exercises there, as well as by mushroom and berry pickers and fishermen (Peterhofs 2007). There were no signs of fire observed in the sampled area or close to it, and the historical aerial pictures also do not show such signs. The area sampled in this study lies in the south-western part of Ances Dizpurvs mire (Figs. 3AB) and is approximately 40 ha in size.

In the study, long-term monitoring data on water level was available from Lielais Kemeri mire, which could be examined in relation to climatic factors. Lielais Kemeri mire in the Kemeri National Park has a total area of 6192 ha and is among the largest mires in Latvia (Fig. 1). Average depth of the peat is $4.8 \mathrm{~m}$, and the maximum peat depth reaches $8 \mathrm{~m}$ (Galenieks, Krauklis 1995). Most of the mire is a typical raised bog with bog-pools, hollows and hummock complexes, and is minimally affected by drainage. It is mostly covered with typical raised bog vegetation. The central part is relatively open, but sparse pine overgrowth occurs, particularly in the periphery (Priede 2013).

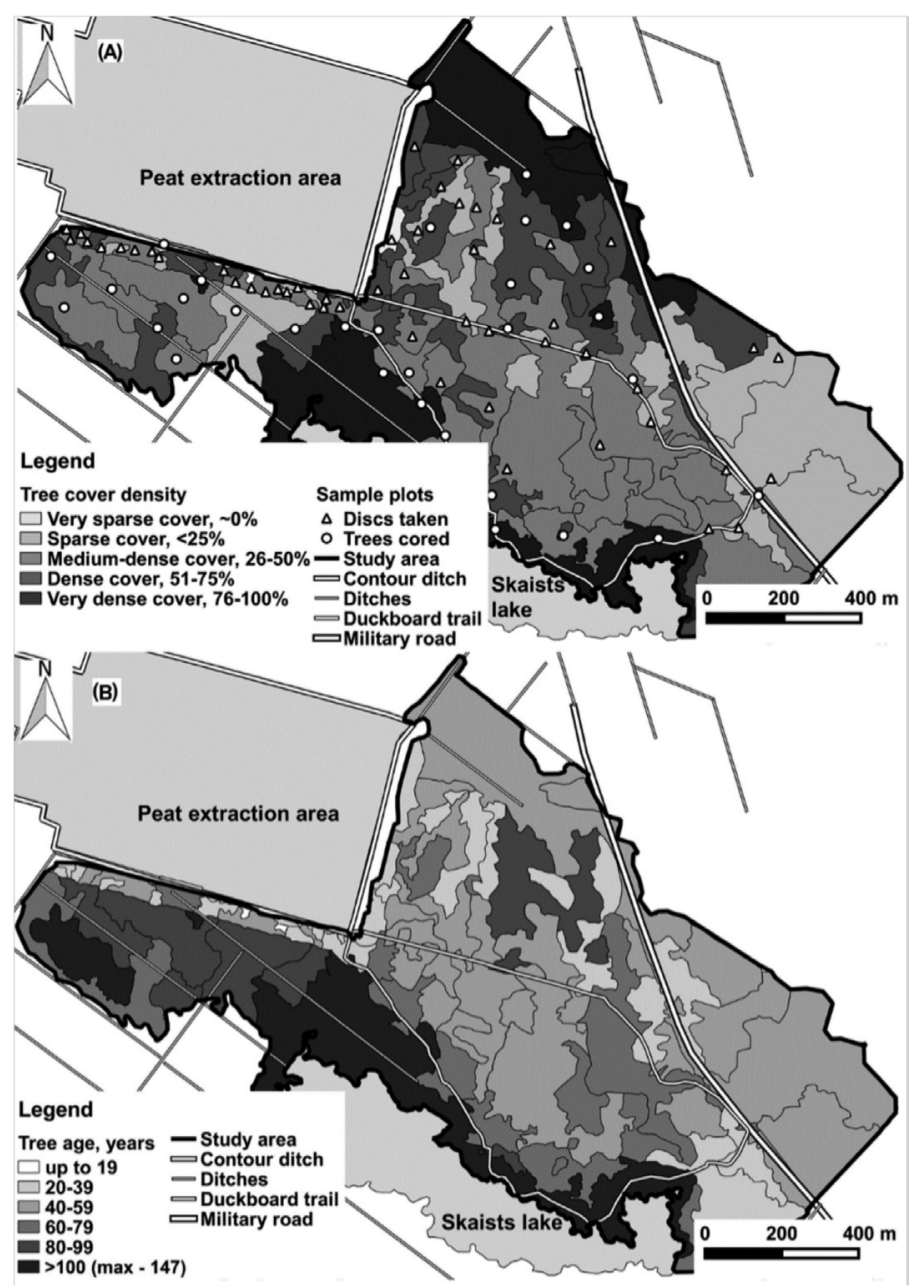

Fig. 2. A, map of Scots pine cover density (shaded polygons) with sample plot locations in Cena mire study area. B, map of Scots pine age (shaded polygons) in Cena mire study area. 


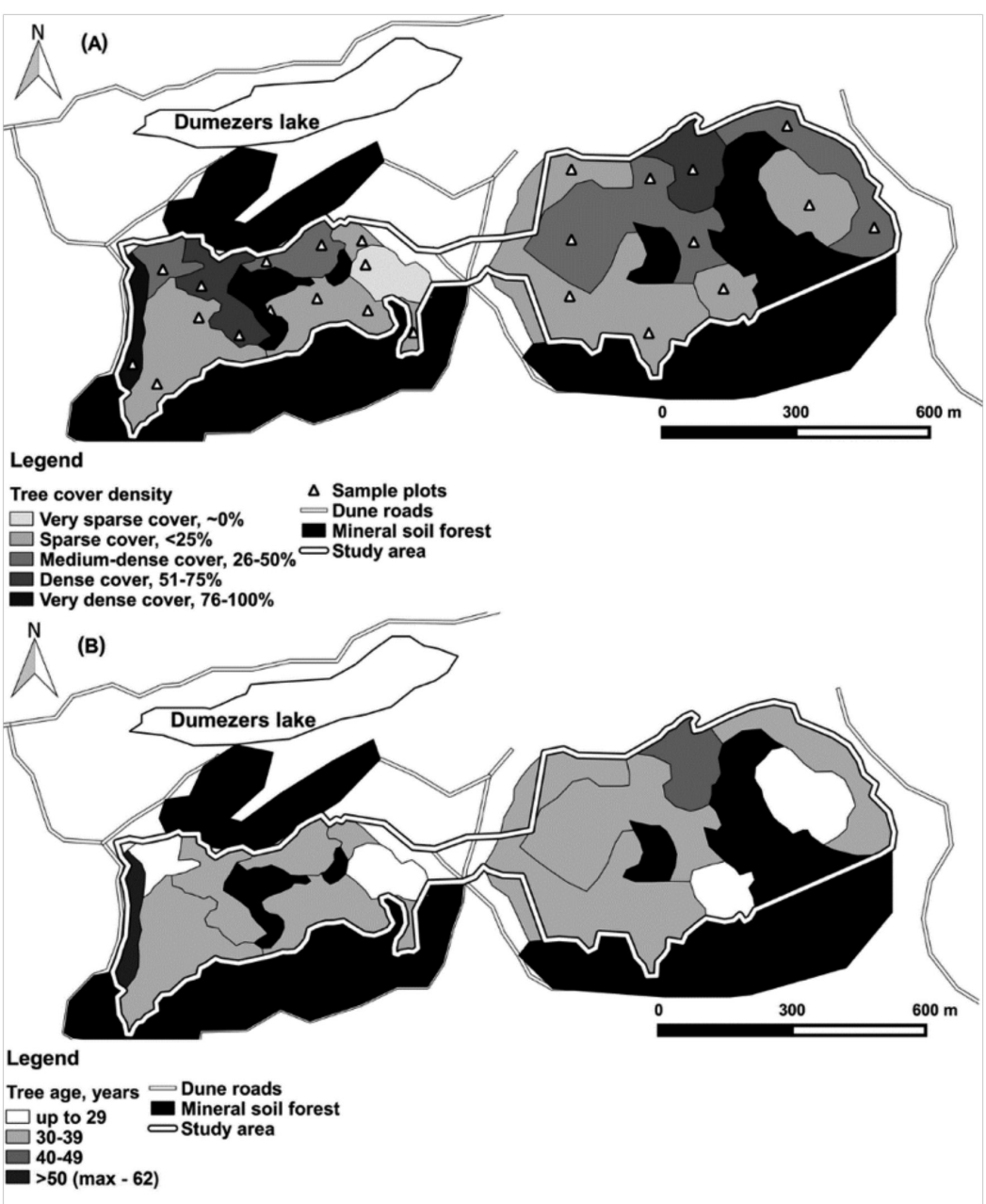

Fig. 3. A, map of Scots pine cover density (shaded polygons) with sample plot locations in Ances Dizpurvs mire study area. B, map of Scots pine age (shaded polygons) in Ances Dizpurvs mire study area.

\section{Orthophoto analysis, sampling and map preparation}

To characterize the bog tree cover structure, orthophoto colour images (resolution $0.5 \mathrm{~m}$ ) from 2007 were analyzed. Five groups of tree crown cover density were delineated: (1) very sparse cover, separate trees, (2) sparse cover, crown cover projection up to $25 \%$, (3) medium-dense cover, crown cover projection 26 to $50 \%$, (4) dense cover, crown cover projection 51 to $75 \%$ and (5) very dense cover, crown cover projection 76 to $100 \%$. These classes of crown cover were easily recognized on the orthophoto maps. Homogenous polygons with these classes of crown cover of Scots pine (as virtually the only tree species) were mapped using GIS (ESRI ArcMap 10 and QGIS 2.8.2. software). Average individual tree crown size was visually estimated for each of the polygons at a 3-point scale. Areas with the same crown cover density but differing average tree crown size were drawn as separate polygons. For Cena mire, the minimum polygon area was $\sim 500 \mathrm{~m}^{2}$, maximum $\sim 18 \mathrm{ha}$, and mean $\sim 1.8$ ha. For Ances Dizpurvs mire, the minimum polygon area was $\sim 0.5$ ha, maximum $\sim 10$ ha, and mean $\sim 2.9$ ha.

In each pine cover density polygon, depending on its size, one to three (in the largest polygons, up to six) sampling plots $(20 \times 20 \mathrm{~m})$ were randomly established, in which three to four trees of the most frequent height were sampled for age determination. Diameter at root collar and height of the sampled trees from root collar were also measured. It was assumed that age of these tree would represent to the main period of colonization. The sampled smaller trees (root collar diameter $<5 \mathrm{~cm}$ ) were felled, and disks from their trunks were taken from as close to the ground as possible. Larger trees (root collar diameter $>5 \mathrm{~cm}$ ) were cored with an increment borer as close to the ground as possible. Height for trees $<3 \mathrm{~m}$ height was measured in the field using a pole. For taller trees, the mean height was estimated using a Suunto clinometer. In this study we focused on trees that had recruited past the seedling stage, i.e. were taller than approximately $0.5 \mathrm{~m}$, as these had survived juvenile mortality and likely had higher ecological importance in forming the current bog tree stands.

In the laboratory, the wood samples were dried and sanded. For the age estimation, annual rings of trees were counted using a Leica MS5 microscope. 
The maximum recorded tree age was assigned to the individual polygons (Fig. 2B, 3B) as the estimated age of the corresponding stand. Stand age of some polygons that were left unsampled ( 22 of 84 polygons) due to time constraints was estimated as the mean of the ages of surrounding sampled polygons.

\section{Hydrometeorological data and data analysis}

For climate data we used series of yearly mean precipitation recorded in the Riga-University (the closest station to Cena mire) and Ventspils meteorological stations (closest to Ances Dizpurvs mire). Records for Riga date back to 1851, and for Ventspils to 1926. The data were archived by the "Latvian Environment, Geology and Meteorology Centre" and were kindly provided by Agrita Briede, University of Latvia. To remove year-to-year fluctuations of precipitation, a 5-year moving average curve (successive means of 5-year periods) was produced. Important peak dry periods with low precipitation were determined visually from plots as the periods with moving average precipitation line below the mean long-term precipitation for at least 10 consecutive years.

The timing of drainage in Cena mire was determined from literature (Silamikele 2005), topographic maps (1936 Latvian army topographic mosaic in scale $1: 75000$, USSR army 1942 and 1963 system topographic mosaic map in scale 1 : 25000) and information provided by drainage expert Juris Nusbaums (2011, personal communication). The USSR 1942 system topographic map covering the research area was surveyed in 1961 to produce a new map. Likewise, 1963 system topographic mosaic map was again resurveyed in 1981.

In Lielais Kemeri mire, hydrological monitoring in wells was conducted daily between 1949 and 1996 (data from 1973 is missing). Monitoring data of mire groundwater level (depth from the surface of mire to groundwater) were obtained from "Latvian Environment, Geology, and Meteorology Centre". We used data from the well with the longest record of measurements, which was located about $500 \mathrm{~m}$ from the edge of the mire in an area colonized by Scots pine.

\section{Results}

Construction of the drainage system in Cena mire started in 1933 and proceeded in several stages (Silamikele 2005). Ditches reaching the surroundings of Skaists lake in the western part of the study area were dug between 1933 and 1945. The contour ditch around the peat extraction site was dug in 1978 (Nusbaums 2011, personal communication). As an average weighted by polygon area, pine cover projection in Cena mire study area was $55 \%$. In the drained Cena mire, the densest Scots pine stand cover (76 to 100\% crown projection) was recorded along the mire margin, on the banks of Skaists lake and along the former military road, as well as around the bog pool systems to the East from Skaists lake (Fig. 2A). Medium crown cover density occurred in the middle part of the study area. The lowest crown cover density was found in the north-eastern part of the study area, where vegetation typical for a transitional mire dominated. Most of the trees had height 0.8 to $2.5 \mathrm{~m}$.

Near Skaists lake, the average tree height was four to six meters, while the tallest trees reached $13 \mathrm{~m}$ in height. Tree height decreased with increasing distance from the mire margin.

The oldest trees were found in the western part of Cena mire study area next to the drainage ditches and on the banks of Skaists lake (Fig. 2B), where the highest tree cover density was also recorded (Fig. 2A). The age of several Scots pine trees there reached 147 years (Dauskane et al. 2011).

Tree age in spatial polygons, estimated as age of the oldest tree sampled in a polygon (start of colonization) varied from 18 to 116 in Cena mire (Table 1) and 27 to 62 on Ances Dizpurvs mire (Table 2). In each polygon age class (defined from maximum age of sampled trees in polygons), there was wide difference between minimum and maximum ages of sample trees, which conforms to a long period of tree colonization.

Maximum age of trees in a stand on the banks of Skaists lake that we recorded was 116 years, while tree ages up to 147 years were recorded in the same area by Dauskane (2010). Trees with age 20 to 39 years were located mostly along the peat extraction field and in the central part of the

Table 1. Summary statistics for trees sampled in Cena mire by age class. Age classes are corresponding to the map polygon symbolization (Fig. 2B). Age class was defined by maximum age of sampled trees in polygons. Minimum and mean ages refer to values for these classes. ${ }^{*}$ Maximum age of 147 years taken from Dauskane (2010)

\begin{tabular}{|c|c|c|c|c|c|c|}
\hline Age classes (years) & $\begin{array}{c}\text { Maximum age } \\
\text { (years) }\end{array}$ & $\begin{array}{c}\text { Minimum age } \\
\text { (years) }\end{array}$ & $\begin{array}{c}\text { Mean age } \\
\text { (years) }\end{array}$ & $\begin{array}{c}\text { Age standard } \\
\text { deviation }\end{array}$ & Polygon count & $\begin{array}{c}\text { Polygon area } \\
\text { (ha) }\end{array}$ \\
\hline $0-19$ & 18 & 15 & 16 & 1.5 & 1 & 0.5 \\
\hline $20-39$ & 39 & 13 & 27 & 5.4 & 26 & 21.2 \\
\hline $40-59$ & 58 & 22 & 39 & 8,1 & 20 & 63.7 \\
\hline $60-79$ & 77 & 32 & 59 & 9.9 & 15 & 23.9 \\
\hline $80-99$ & 95 & 37 & 71 & 13.4 & 9 & 17.8 \\
\hline$>100$ & $147^{\star}$ & 67 & 89 & 9.1 & 3 & 21.9 \\
\hline Total: & & & & & 84 & 149.0 \\
\hline
\end{tabular}


Table 2. Summary statistics for trees sampled in Ances dižpurvs mire by age class. Age classes are corresponding to the map polygon symbolization (Fig. 3B). Age class was defined by maximum age of sampled trees in polygons. Minimum and mean ages refer to values for these classes

\begin{tabular}{|c|c|c|c|c|c|c|}
\hline Age classes (years) & $\begin{array}{c}\text { Maximum age } \\
\text { (years) }\end{array}$ & $\begin{array}{c}\text { Minimum age } \\
\text { (years) }\end{array}$ & $\begin{array}{c}\text { Mean age } \\
\text { (years) }\end{array}$ & $\begin{array}{c}\text { Age standard } \\
\text { deviation }\end{array}$ & Polygon count & $\begin{array}{c}\text { Polygon area } \\
\text { (ha) }\end{array}$ \\
\hline $0-29$ & 27 & 22 & 25 & 2.4 & 3 & 5.8 \\
\hline $30-39$ & 39 & 22 & 33 & 4.4 & 9 & 33.0 \\
\hline $40-49$ & 46 & 28 & 38 & 5.5 & 1 & 2.3 \\
\hline$>50$ & 62 & 26 & 45 & 12.4 & 1 & 1.1 \\
\hline Total: & & & & & 14 & 42.2 \\
\hline
\end{tabular}

study area, trees 40 to 59 years were mostly in the central part (Fig. 2B). Trees of age between 80 to 99 years were mostly located near the ditch system in the western part of the study area. Thus, except for older age classes occurring at the edge of Skaists lake, the spatial variability of tree age of polygons did not show a gradual trend from edges nor from ditches; rather, the stand tree age showed a mosaic pattern. The main period of Scots pine regeneration in the drained Cena mire study area was approximately during 1960 to 1990.

In the undrained Ances Dizpurvs mire study area, sparse and medium-dense Scots pine cover dominated (Fig. 3A). As an average weighted by polygon area, pine cover projection in Ances Dizpurvs mire study area was 27 $\%$. The height of pine was generally less than three meters, with the maximum height reaching $12 \mathrm{~m}$ in one of the polygons. The tree age in that polygon was 55 years. Most of the trees in the bog had age 30 to 39 years, i.e. recruited approximately between 1970 and 1980 (Fig. 3B).

Five dry periods lasting at least 10 years could be distinguished (1854 to 1881,1887 to 1903,1935 to 1946 , 1966 to 1979 , and 1997 to 2007) in long-term precipitation data from the Riga-University meteorological station (Fig. $4 \mathrm{~A})$. The oldest trees that were recorded by Dauskane (2010) appeared in Cena mire in the first dry period (1854 to 1881). The fourth dry period (1966 to 1979) chronologically overlapped with the widely distributed young pine cover age classes, i.e. trees between 20 and 39; and 40 and 59 years old, which were also abundant in the Ances Dizpurvs mire study area (Fig. 3B). Also in Lielais Kemeri mire dataset a considerable drop in groundwater level was observed during the same fourth dry period. The start of decrease of water level began after a two-year lag, beginning in 1961 (Fig. 5).

In the precipitation dynamics recorded at Ventspils meteorological station, near the undrained Ances Dizpurvs mire, two dry periods lasting at least 10 years could be distinguished: 1940 to 1961 and 1963 to 1979 . A 1963 to 1979 dry period was observed during the time period when the most of the trees, which were 30 to 60 years old, colonized the mire (Figs. 3B, 4B).

\section{Discussion}

Undoubtedly, the installation of the drainage system in the Cena mire study area had considerable impact on the development of Scots pine cover. Establishment of the contour ditch in 1978 could have promoted pine recruitment, but the possibly affected tree stand age group covers only a small part of the study area. The contour ditch was dug after recruitment of the trees 30 to 50 years old, and the oblique ditches reaching near Skaists lake are surrounded also partially by pine stands older than these ditches (Fig. 2B). The ditches in the vicinity of Skaists lake, which were dug starting from 1933, certainly influenced the development of pine cover there; however, presumably, they were not the defining factor in the spatial development of this pine cover. Trees on the banks of Skaists lake, which are more than 100 years old (Fig. 2B), probably developed without direct human influence, possible due to better drainage conditions near a water-body. Thus, pine establishment in the studied mires occurred due to both natural and human-caused factors, as previously shown in a study in Lithuania (Edvardsson et al. 2015).

The study showed that timing of Scots pine establishment in Ances Dizpurvs, which had not been affected by drainage, coincided very well with favourable phases of temperature and precipitation in the period 1966 to 1979 . In the Cena mire, overgrowing with Scots pine also occurred at that time, which might be attributed to a drainage effect, but the establishment had already occurred before drainage in the 1900. The influence of temperature and precipitation via effect of groundwater level on radial growth of Scots pine in Cena mire was shown previously (Dauskane 2010). Water level in mires controls the regeneration and survival of seedlings, and determines pine stand structure and dynamics (Ågren, Zackrisson 1990; Ohlson, Zackrisson 1992; Sarkkola et al. 2004). A high water level is associated with poor establishment and growth of trees (Ohlson 1995; MacDonald, Yin 1999; Hökkä, Ojansuu 2004). Trees survive better on hummocks, where the groundwater table is deeper (Gunnarsson 2000). 

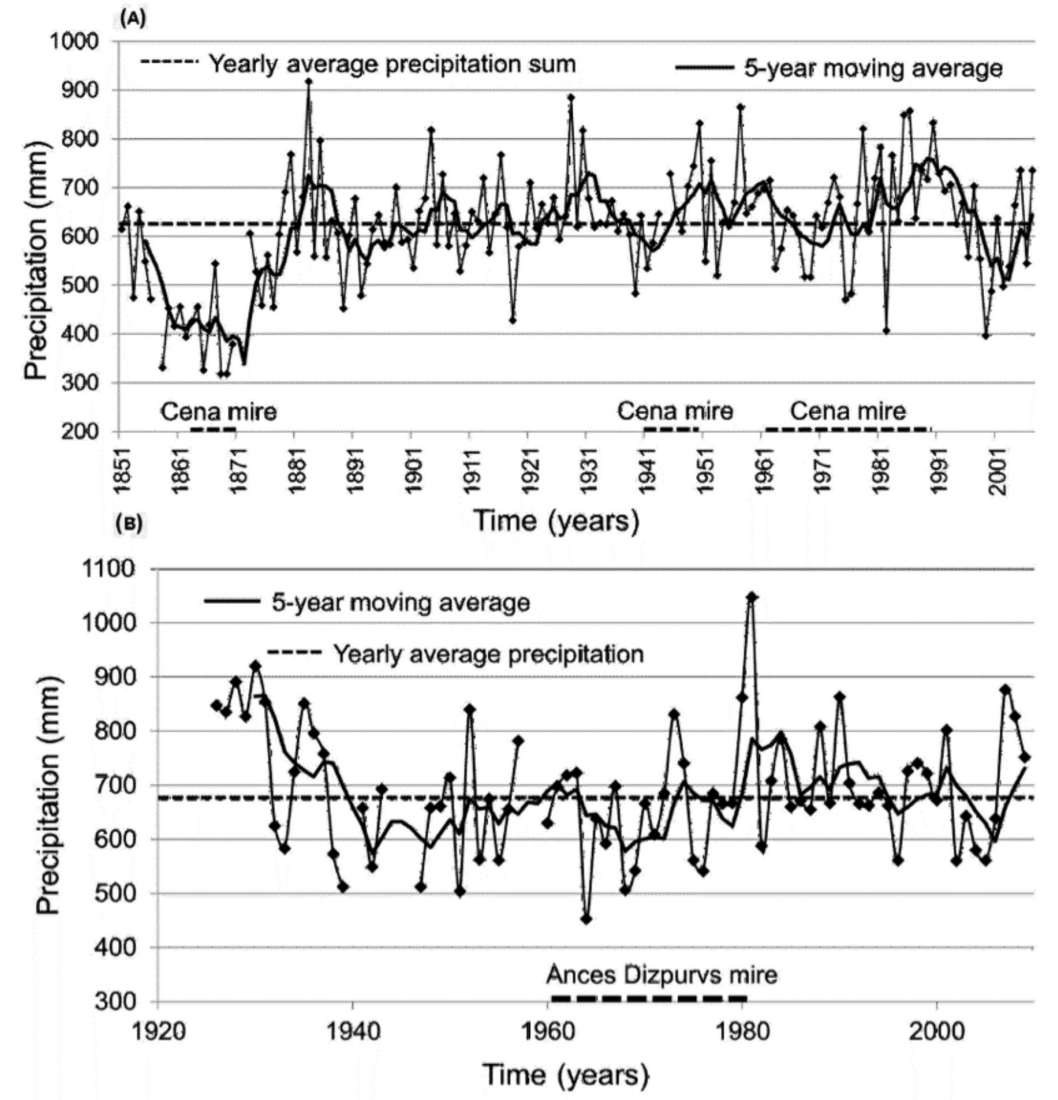

Fig. 4. A, long-term yearly precipitation sum diagram from Riga-University meteorological station with a 5-year moving average. Thick dashed lines on the time scale at bottom shows major periods of Scots pine recruitment in Cena mire study area. B, long-term yearly precipitation sum diagram for Ventspils meteorological station with a 5-year moving average. Thick dashed lines on the time scale at bottom shows major periods of Scots pine recruitment in Ances Dizpurvs mire study area. ${ }^{\star}$ Important major periods of Scots pine recruitment were considered qualitatively from previous studies and currently collected spatial data visualizations in GIS medium.

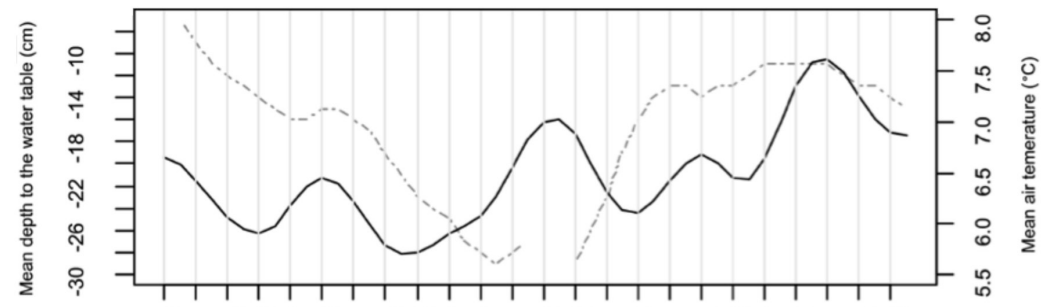

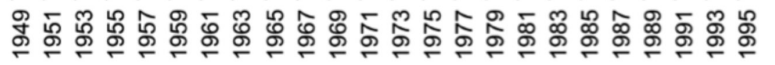

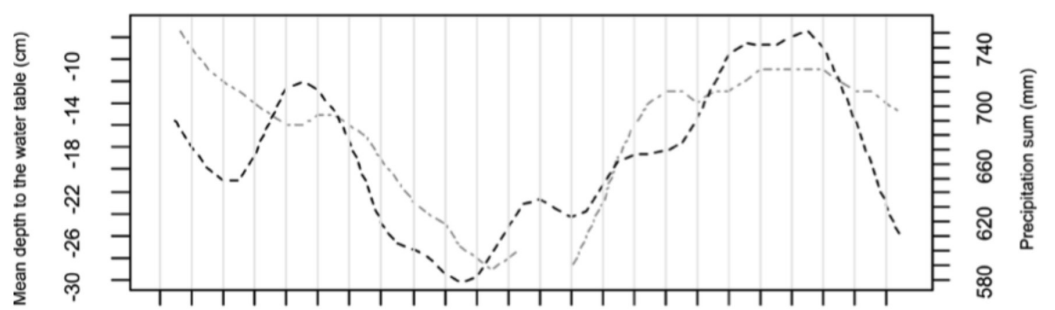

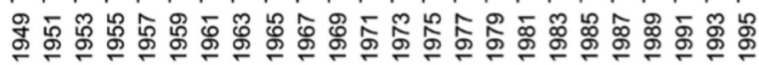

Year

Fig. 5. Long-term changes in the mean annual air temperature (solid line), annual precipitation sum (black dash line) and the mean annual depth of water table (grey dash line) from 1949 to 1996 in Lielais Kemeri mire. For the mean annual depth of water table and climatic factors (temperature and precipitation), high frequency year-to-year fluctuations were removed by calculating a 10-year moving average. Adapted from Dauskane (2010). 
The periods of Scots pine recruitment in our study sites were associated with a significant increase of Scots pine radial growth in other bogs in Latvia and Sweden (Ågren et al. 1983; Linderholm 2001; Linderholm et al. 2002; Dauskane 2010). During those periods, summers were very warm, especially during the 1930's (Briffa, Jones 1993), which promoted regeneration and radial growth for pines growing in mires. An increase in air temperature and a decrease in precipitation and therefore also in ground water level in mires for the period from the early 1960's to mid-1970's was characteristic for Latvia (Dauskane 2010). Data from Lielais Kemeri mire support these observations (Fig. 5).

Air temperature has also a direct effect on the establishment and growth of trees (Linderholm et al. 2002). As the water level decreases, decreasing the main limiting factor, trees react more to the impact of air temperature and precipitation (Dauskane 2010). In Latvia, a steady increase in the yearly mean temperature since 1913 has been shown by Lizuma et al. (2007). A higher temperature increases evapotranspiration and lowers the groundwater table in peatlands, creating favourable conditions for colonisation by pines (Gunnarsson 2000). Zackrisson et al. (1995) observed that Scots pine regeneration pulses in boreal forests lag behind the temperature increase by 20 to 30 years. They explained this lag by the great variation in seed production, quality and germination ability, as well as variation in seedling survival caused by climate variability, and by gradual changes in the understorey vegetation composition towards a more favourable one for Scots pine development (Zackrisson et al. 1995). Studies on the Lielais Kemeri mire in Latvia have demonstrated that there is gap in time between a change of climate and effect on the water levels (Dauskane 2010).

Gradual climate changes do not immediately affect the ground water level (Kilian et al. 1995). Low air temperature and high precipitation facilitate the accumulation of water in mires, and in dry times these stocks are slowly consumed as a result of evapotranspiration (Linderholm et al. 2002). However, the period of increasing temperature overlaps with the timing of pine cover establishment in the Cena mire (Fig. 2B) and Ances Dizpurvs mire (Fig. 3B) study areas. This can be explained by the climate hypothesis in palaeoecological studies on bog trees (Eckstein et al. 2009; Edvardsson et al. 2012), where historical Holocene treecovered phases were related to climate variability and regional wetness.

Our study suggests climate variability to be a main factor that likely influenced Scots pine cover development in both drained and undrained raised bogs in Latvia, as we observed a temporal overlap between favourable climate phases and bog pine cover development. While drainage remains one of the most important factors operating in drained bogs, this study demonstrated that similar processes of vegetation shifts can take place in both drained and undrained raised bogs. Therefore, drainage is not the only nor always the primary driving factor for Scots pine cover development in raised bogs in Latvia. This reflects the great need to stress that the dynamics of mire vegetation are determined by a combination of several factors that all have to be considered in developing mire management plans for protected nature areas, as suggested earlier (Tuittila et al. 2007).

\section{Acknowledgements}

Most of the financing for the study came from the European Social Fund as well as by a grant of the Latvian Council of Science No. 6198. We thank Roberts Matisons for help at the initial stages of the study.

\section{References}

Ågren J., Zackrisson O. 1990. Age and size structure of Pinus sylvestris populations on mires in central and northern Sweden. J. Ecol. 78: 1049-1062.

Ågren J., Isaksson L., Zackrisson O. 1983. Natural age and size of Pinus sylvestris and Picea abies on mire in the inland part of Northern Sweden. Holarct. Ecol. 6: 228-237.

Briffa K.R., Jones P.D. 1993. Global surface air temperature variations during the twentieth century: Part 2, implications for large-scale high-frequency palaeoclimatic studies. Holocene 3: 77-88.

Dauskane I. 2010. The relationship of the radial growth of Scots pine Pinus sylvestris L. growing on bogs with climatic factors in Latvia. Doctoral thesis. Rìga, University of Latvia, Faculty of Biology, 137 pp. [in Latvian]

Dauskane I., Brumelis G., Elferts D. 2011. Effect of climate on extreme radial growth of Scots pine growing on bogs in Latvia. Estonian J. Ecol. 60: 236-248.

Eckstein J., Leuschner H.H., Bauerochse A., Sass-Klaassen U. 2009. Subfossil bog-pine horizons document climate and ecosystem changes during the Mid-Holocene. Dendrochronologia 27: 129-146.

Edvardsson J., Leuschner H.H., Linderson H., Linderholm H.W., Hammarlund D. 2012. South Swedish bog pines as indicators of Mid-Holocene climate variability. Dendrochronologia 30: 93-103.

Edvardsson J., Simanauskiene R., Taminskas J., Bauziene I., Stoffel M. 2015. Increased tree establishment in Lithuanian peat bogs - Insights from field and remotely sensed approaches. Sci. Total Environ. 505: 113-120.

Frelechoux F., Buttler A., Gillet F. 2000a. Dynamics of bogpine-dominated mires in the Jura mountains, Switzerland: a tentative scheme based on synusial phytosociology. Folia Geobot. 35: 273-288.

Frelechoux F., Buttler A., Schweingruber F.H., Gobat J.M. 2000 b. Stand structure, invasion, and growth dynamics of bog pine (Pinus uncinata var. rotundata) in relation to peat cutting and drainage in the Jura Mountains, Switzerland. Can. J. Forest Res. 30: 1114-1126.

Frelechoux F., Buttler A., Gillet F., Gobat J.M., Schweingruber F.H. 2003. Succession from bog pine (Pinus uncinata var. rotundata) to Norway spruce (Picea abies) stands in relation to anthropic factors in Les Saignolis bog, Jura Mountains, Switzerland. Ann. Forest Sci. 60: 347-356. 
Galenieks I., Krauklis I. 1995. Kemeru mire. Latvijas Daba. Enciklopēdija. Preses Nams, Rīga. 3, 61. [in Latvian]

Gunnarsson U. 2000. Vegetation changes on Swedish mires. Effects of raised temperature and increased nitrogen and sulphur influx. Acta Universitatis Upsaliensis. Comprehensive Summaries of Uppsala Dissertations from the Faculty of Science and Technology 561, Uppsala, 25 pp.

Holden J., Shotbolt L., Bonn A., Burt T.P., Chapman P.J., Dougill A.J., Fraser E.D.G., Hubacek K., Irvine B.J., Kirkby M.J., Prell C., Reed M.S., Stagl S., Stringer L.C., Turner A.G.D., Worall F. 2007. Environmental change in moorland landscapes. Earth Sci. Rev. 82: 75-100.

Hökkä H., Ojansuu R. 2004. Height development of Scots pine on peatlands: describing change in site productivity with a site index model. Can. J. Forest Res. 34: 1081-1092.

Hökkä H., Alenius V., Penttilä T. 1997. Individual-tree basal area growth models for Scots pine, pubescent birch and Norway spruce on drained peatlands in Finland. Silva Fennica 31: $161-178$.

Kalnina L. 2008. The formation and development of mires in Latvia. In: Pakalne M. (ed) Mire Protection and Management in Specially Protected Areas in Latvia. Latvian Fund for Nature, Rìga, pp. 20-25. [in Latvian]

Kilian M.R., Van der Plicht J., Van Geel B. 1995. Dating raised bogs. New aspects of AMS 14C wiggle matching, a reservoir effect and climatic change. Quat. Sci. Rev. 14: 959-966.

Kont A., Endjärv E., Jaagus J., Lode E., Orviku K., Ratas U., Rivis R., Suursaar Ü., Tõnisson H. 2007. Impact of climate change on Estonian coastal and inland wetlands - a summary with new results. Boreal Environ. Res. 12: 653-671.

Kucerova A., Rektoris L., Stechova T., Bastl M. 2008. Disturbances on a wooded raised bog - how windthrow, bark beetle and fire affect vegetation and soil water quality? Folia Geobot. 43: 49-67.

Kuze J., Priede A. 2008. Raising of the water level in Kemeri mire drainage-affected areas: methods and first results. In: Pakalne M. (ed) Mire Protection and Management in Specially Protected Areas in Latvia. Latvian Fund for Nature, Rīga, pp. 132-141. [in Latvian]

Latvian Fund for Nature 2008. Cena mire, available at http://old. ldf.lv/pub/?doc_id=28256

Linderholm H.W. 1999. Climatic and anthropogenic influences on radial growth of Scots Pine at Hanvedsmossen, a raised peat bog, in south central Sweden. Geogr. Ann. A Phys. Geogr. 81: $75-86$.

Linderholm H.W. 2001. Climatic influence on Scots pine growth on dry and wet soils in the central Scandinavian Mountains, interpreted from tree-ring widths. Silva Fenn. 35: 415-424.

Linderholm H.W., Leine M. 2004. An assessment of twentieth century tree-cover changes on a southern Swedish peatland combining dendrochronology and aerial photograph analysis. Wetlands 24: 357-363.

Linderholm H.W., Moberg A., Grudd H. 2002. Peatland pine as a climate indicator? A regional comparison of the climatic influence on Scots pine growth in Sweden. Can. J. Forest Res. 32: $1400-1410$.

Lizuma L., Klavins M., Briede A., Radionovs V. 2007. Long-term changes of air temperature in Latvia. In: Klavins M. (ed) Climate Change in Latvia. University of Latvia, Rìga, pp. 11-19.

Macdonald S.E., Yin F. 1999. Factors influencing size inequality in peatland black spruce and tamarack: evidence from postdrainage release growth. J. Ecol. 87: 404-412.
Mitchell E.A.D., van der Knaap W.O., van Leeuwen J.F.N., Buttler A., Warner B.G., Gobat J.M. 2001. The palaeoecological history of Praz-Rodet bog (Swiss Jura) based on pollen, plant macrofossils and testate Amoeba (Protozoa). Holocene 11: 65-80.

Moir A.K., Leroy S.A.G., Brown D., Collins P.E.F. 2010. Dendrochronological evidence for a lower water-table on peatland around 3200-3000 BC from subfossil pine in northern Scotland. Holocene 20: 931-942.

Nusbaums J. 2008. Prevention of drainage effects in raised bogs. In: Pakalne M. (ed) Mire Protection and Management in Specially Protected Areas in Latvia. Latvian Fund for Nature, Rìga, pp. 118-131. [in Latvian]

Obidzinski A., Kloss M., Cedro A. 2009. Is spontaneous regeneration of raised mire vegetation possible? A case study of the 'Czarne Bagno' mire in the Bystrzyckie Hills, southern Poland. Holocene 19: 229-239.

Ohlson M. 1995. Growth and nutrient characteristics in bog and fen populations of Scots pine (Pinus sylvestris). Plant Soil 172: 235-245.

Ohlson M., Zackrisson O. 1992. Tree habitat establishment and microhabitat relationships in north Swedish peatlands. Can. J. Forest Res. 22: 1869-1877.

Ohlson M., Okland R.H., Nordbakken J.F., Dahlberg B. 2001. Fatal interactions between Scots pine and Sphagnum mosses in bog ecosystems. Oikos 94: 425-432.

Pakalne M. 2008. Mire habitats and their protection. In: Pakalne M. (ed) Mire protection and management in specially protected areas in Latvia. Latvian Fund for Nature, Rìga, pp. 8-19. [in Latvian]

Pellerin S., Lavoie C. 2003. Recent expansion of jack pine in peatlands of southeastern Quebec: A paleoecological study. Ecoscience 10: 247-257.

Peterhofs E. (ed) 2007. Nature protection plan for specially protected area's nature reserve "Ance mires and forests" for years 2007-2016. SIA ”REMM”, 206 pp. [in Latvian]

Priede A. 2013. Changes in vegetation in the former peat milling fields after hydrological restoration in Lielais Kemeri Mire. In: Pakalne M., Strazdiña L. (eds) Raised Bog Management for Biological Diversity Conservation in Latvia. Hansa Print Riga, Rìga, pp. 207-216.

Ronkainen T., Väliranta M., Tuittila E.S. 2013. Fire pattern in a drainage-affected boreal bog. Boreal Environ. Res. 18: 309-316.

Sarkkola S., Hökkä H., Penttilä T. 2004. Natural development of stand structure in peatland Scots pine following drainage: results based on long-term monitoring of permanent sample plots. Silva Fenn. 38: 405-412.

Sarkkola S., Hökkä H., Laiho R., Päivänen J., Penttilä T. 2005. Stand structural dynamics on drained peatlands dominated by Scots pine. Forest Ecol. Manage. 206: 135-152.

Silamikele I. (ed) 2005. Nature protection plan for years 20052020 for "Cena mire" nature reserve. Latvian Fund for Nature, Rīga, 72 pp. [in Latvian]

Tuittila E.S., Väliranta M., Laine J., Korhola A. 2007. Quantifying patterns and controls of mire vegetation successions in a southern boreal bog in Finland using partial ordinations. J. Veget. Sci. 18: 891-902.

Vasander H., Tuittila E.S., Lode E., Lundin L., Ilomets M., Sallantaus T., Heikkilä R., Pitkänen M.L., Laine J. 2003. Status and restoration of peatlands in northern Europe. Wetlands Ecol. Manage. 11: 51-63.

Van der Linden M., Vickery E., Charman D.J., van Geel B. 2008. 
Effects of human impact and climate change during the last 350 years recorded in Swedish raised bog deposit. Palaeogr. Palaeoclimatol. Palaeoecol. 262: 1-31.
Zackrisson O., Nilsson M.-C., Steijlen I., Hörnberg G. 1995. Regeneration pulses and climate-vegetation interactions in nonpyrogenic boreal Scots pine stands. J. Ecol. 83: 469-483. 